\title{
Mechanical Properties and Porosity of Dental Glass-Ceramics Hot-Pressed at Different Temperatures
}

Carla Castiglia Gonzaga ${ }^{\mathrm{a}}$, Paulo Francisco Cesar ${ }^{\mathrm{a} *}$, Cristina Yuri Okada $^{\mathrm{a}}$;

Catia Fredericci ${ }^{\mathrm{b}}$, Flávio Beneduce Neto ${ }^{\mathrm{b}}$, Humberto Naoyuki Yoshimura $^{\mathrm{b}}$

${ }^{a}$ Department of Biomaterials and Oral Biochemistry, School of Dentistry,

University of São Paulo, Av. Prof. Lineu Prestes, 2227, 05508-900

Cidade Universitária “Armando Salles de Oliveira”, São Paulo - SP, Brazil

${ }^{\mathrm{b}}$ Laboratory of Metallurgy and Ceramic Materials,

Institute for Technological Research of the State of São Paulo - SP, Brazil

Received: April 25, 2008; Revised: August 26, 2008

\begin{abstract}
The objective of this work was to evaluate biaxial-flexural-strength $\left(\sigma_{f}\right)$, Vickers hardness $(\mathrm{HV})$, fracture toughness $\left(\mathrm{K}_{\mathrm{IC}}\right)$, Young's modulus $(\mathrm{E})$, Poisson's ratio $(\mathrm{V})$ and porosity $(\mathrm{P})$ of two commercial glass-ceramics, Empress (E1) and Empress 2 (E2), as a function of the hot-pressing temperature. Ten disks were hot-pressed at $1065,1070,1075$ and $1080{ }^{\circ} \mathrm{C}$ for $\mathrm{E} 1$; and at $910,915,920$ and $925{ }^{\circ} \mathrm{C}$ for $\mathrm{E} 2$. The porosity was measured by an image analyzer software and $\sigma_{\mathrm{f}}$ was determined using the piston-on-three-balls method. $\mathrm{K}_{\mathrm{Ic}}$ and $\mathrm{HV}$ were determined by an indentation method. Elastic constants were determined by the pulse-echo method. For E1 samples treated at different temperatures, there were no statistical differences among the values of all evaluated properties. For E2 samples treated at different temperatures, there were no statistical differences among the values of $\sigma_{\mathrm{f}}$, E, and $v$, however $\mathrm{HV}$ and $\mathrm{K}_{\mathrm{Ic}}$ were significantly higher for 910 and $915^{\circ} \mathrm{C}$, respectively. Regarding $\mathrm{P}$, the mean value obtained for $\mathrm{E} 2$ for $925^{\circ} \mathrm{C}$ was significantly higher compared to other temperatures.
\end{abstract}

Keywords: dental glass-ceramics, injection temperature, mechanical properties, porosity

\section{Introduction}

The increasing demand for aesthetic materials in Dentistry has pushed on the development of novel all-ceramic systems. Besides excellent esthetics, these materials have high strength, good color stability, high resistance to wear, and high biocompatibility ${ }^{1}$. A number of all-ceramic systems are currently available for dental restorations. Among these, glass-ceramics are one of the most popular due to their good marginal fit, good mechanical properties and low porosity compared to conventional feldspathic porcelains ${ }^{2,3}$.

Glass-ceramics are produced by the controlled crystallization method, in which the crystalline phases are nucleated and grown in a glass by means of a heat treatment ${ }^{4}$. The microstructure and chemical composition of a glass-ceramic both determine the general physical, chemical and optical properties of the final material ${ }^{5}$. IPS Empress (E1) (Ivoclar, Schaan, Liechtenstein) is a leucite-reinforced hot-pressed glass-ceramic that was released in the market in the early 1990s. This material may be used to fabricate veneers, inlays, onlays and crowns. The chemical composition is based on the $\mathrm{SiO}_{2}-\mathrm{Al}_{2} \mathrm{O}_{3}-$ $\mathrm{K}_{2} \mathrm{O}$ system and the microstructure consists of evenly dispersed leucite $\left(\mathrm{KAlSi}_{2} \mathrm{O}_{6}\right)$ crystals embedded in a glassy matrix ${ }^{6,7}$. The leucite content ranges from 36 to $40 \%$ in volume $\mathrm{i}^{7-9}$.

In 1998, the same manufacturer developed another glass-ceramic, IPS Empress 2 (E2), which contains lithium disilicate $\left(\mathrm{Li}_{2} \mathrm{Si}_{2} \mathrm{O}_{5}\right)$ as the main crystalline phase. It has been shown that elongated interlocked lithium disilicate crystals form $65 \%$ of the microstructure of $\mathrm{E} 2^{7,10-12}$. According to the manufacturer, this material may be used in 3-unit FPDs (fixed partial dentures) up to the second premolar region ${ }^{10}$.

Both glass-ceramics described above are processed by the hotpressing technique. In this method, the waxed pattern of the restoration is invested in a refractory material, which is preheated at $850{ }^{\circ} \mathrm{C}$ for one hour to eliminate wax and create a mold, which is subsequently transferred to a special pressing furnace. The pre-cerammed ingots, supplied by the manufacturer in a variety of shades, are then placed in the open end of the mold and pressed by a thermal resistant alumina plunger attached to the furnace ${ }^{6}$. After yielding through the sprues (connectors), the cavity of the mold is filled by the viscous flow of the glass-ceramic. For the leucite-based material (E1), additional esthetic features can be applied to the full-contour hot-pressed restoration by the use of pigments and glaze (staining technique). In turn, esthetic characterization in the lithium disilicate glass-ceramic (E2) can be achieved by the layering technique. In the first step, only the framework of a crown or FPD is hot-pressed. The final shape of the restoration is obtained by applying a sintered glass-ceramic in layers, which are fired in a conventional porcelain furnace ${ }^{10}$. More recently, the leucite-based material has also been recommended by the manufacturer to be used in the layering technique.

The mechanical properties and microstructure of E1 and E2 glassceramics processed according to manufacturer's recommendations are well documented in the literature. However, only a few studies have evaluated glass-ceramics processed under different hot-pressing temperatures. It has been demonstrated that the microstructure, and consequently the mechanical properties of a glass-ceramic can be modified by varying the thermal treatment to which it is submitted ${ }^{5}$. For instance, it has been shown that the final crystal growth took place during the pressing and firing steps of E1 processing method ${ }^{13}$. One practical aspect of processing that might play a role is the fact that the temperature in the press furnace may oscillate after repeated use. Exactly for this reason, the manufacturer recommends calibration of the equipment after 50 pressing cycles. Problems with furnace calibra- 
tion may lead to high volume fraction of porosity and large pore size in the material, which may jeopardize mechanical properties.

The objective of this study was to evaluate the physical and mechanical properties (biaxial flexure strength, Young's modulus, Poisson's ratio, Vickers hardness and fracture toughness) and the volume fraction of porosity of two glass-ceramics (E1 and E2) hotpressed in different temperatures. The hypothesis to be tested is that differences in injection temperatures will affect the porosity and the mechanical properties.

\section{Materials and Methods}

Two materials were evaluated in the present study: a leucite $\left(\mathrm{KAlSi}_{2} \mathrm{O}_{6}\right.$ ) based glass-ceramic, E1 (IPS Empress, Ivoclar, Schaan, Liechtenstein), with the following composition (in wt. (\%)): $63 \%$ $\mathrm{SiO}_{2}, 17.7 \% \mathrm{Al}_{2} \mathrm{O}_{3}, 11.2 \% \mathrm{~K}_{2} \mathrm{O}, 4.6 \% \mathrm{Na}_{2} \mathrm{O}, 0.6 \% \mathrm{~B}_{2} \mathrm{O}_{3}, 1.6 \% \mathrm{CaO}$, $0.2 \% \mathrm{TiO}_{2}, 0.7 \% \mathrm{BaO}, 0.4 \% \mathrm{CeO}_{2}$, and pigments ${ }^{13}$; and a lithium disilicate $\left(\mathrm{Li}_{2} \mathrm{Si}_{2} \mathrm{O}_{5}\right)$ based glass-ceramic, E2 (IPS Empress 2, Ivoclar, Schaan, Liechtenstein), with the following composition, in wt. (\%): $57-80 \% \mathrm{SiO}_{2}, 11-19 \% \mathrm{Li}_{2} \mathrm{O}, 0-13 \% \mathrm{~K}_{2} \mathrm{O}, 0-11 \% \mathrm{P}_{2} \mathrm{O}_{5}, 0-8 \% \mathrm{ZnO}$, $0-5 \% \mathrm{MgO}, 0.1-6 \% \mathrm{La}_{2} \mathrm{O}_{3}, 0-5 \% \mathrm{Al}_{2} \mathrm{O}_{3}$, and $0-8 \%$ pigments ${ }^{5}$. Forty disks (12 $\mathrm{mm}$ in diameter and $2 \mathrm{~mm}$-thick) of each glass-ceramic were produced according to the manufacturer's instructions. Both materials were processed by the hot-press technique using a specific furnace (EP 600, Ivoclar, Schann, Liechtenstein). For E1, the specimens were hot-pressed at four different temperatures, 1065, 1070,1075 and $1080^{\circ} \mathrm{C}$. For E2, the hot-pressing temperatures were 910, 915, 920 and $925^{\circ} \mathrm{C}$. The control groups were those pressed at 1075 and $920{ }^{\circ} \mathrm{C}$, which are the temperatures recommended by the manufacturer. The other processing parameters used were those recommended by the manufacturer, and ten disks were hot-pressed at each temperature. After pressing, the investment rings were removed from the furnace and allowed to bench cool. Then the disks were removed from the investment ring, and the sprues were cut with a diamond bur (\#740, Vortex, São Paulo, Brazil). The disks were machined to the thickness of $1.0 \mathrm{~mm}$, following the guidelines in ASTM C $1161^{14}$. Then, one of the disk surfaces was mirror polished using a polishing machine (Ecomet 3, Buehler, Lake Bluff, USA) and diamond suspensions $(45,15,6$ and $1 \mu \mathrm{m})$.

The elastic modulus and the Poisson's ratio of the specimens were determined by the pulse-echo method, according to JIS R $1602^{15}$, using an ultrasonic pulser-receiver of $200 \mathrm{MHz}$ (5900 PR, Panametrics, USA) coupled with $20 \mathrm{MHz}$ longitudinal and transversal wave transducers (V208-RM and V222-RM model, Panametrics, USA). A coupling paste (Couplant SWC, Panametrics, USA) was applied between the specimen and the transducer to enhance the ultrasonic pulse signals. The time of flight of the ultrasonic pulse was measured with an oscilloscope (TDS 1002, Tektronix, USA) and the thickness of the sample was measured with a digital micrometer (Mitutoyo, Brazil). Sonic velocities were calculated by: $2 \mathrm{t} / \mathrm{a}$, where $\mathrm{t}$ is the specimen thickness and a is the time of flight ${ }^{16}$. The density of the specimens was determined by the Archimedes' principle, using water as the immersion liquid. The Poisson's ratio, $v$, and Young's modulus, $\mathrm{E}$, were calculated by the following equations:

$$
\begin{gathered}
v=0.5 \cdot \frac{V_{L}^{2}-2 \cdot V_{T}^{2}}{V_{L}^{2}-V_{T}^{2}} \\
E=\rho .\left(\frac{3 \cdot V_{T}^{2} \cdot V_{L}^{2}-4 . V_{T}^{4}}{V_{L}^{2}-V_{T}^{2}}\right)
\end{gathered}
$$

where $\rho$ is the bulk density, $V_{L}$ is the longitudinal velocity, $V_{T}$ is the transversal velocity. ${ }^{15}$
The piston-on-three-balls test was used to determine the biaxial flexure strength. The test was carried out in a universal testing machine (Syntech 5G, MTS, Sao Paulo, Brazil) at a crosshead speed of $0.5 \mathrm{~mm} /$ $\min ^{17}$. The disk specimens were placed over three symmetrically spaced steel balls, and the distance from the center of each ball to the center of the testing device was $8 \mathrm{~mm}$. During the test, the polished surface of the specimen was under tension. Testing was performed at $37^{\circ} \mathrm{C}$ and the specimen was immersed in artificial saliva with the following composition: $100 \mathrm{~mL}$ of $\mathrm{KH}_{2} \mathrm{PO}_{4}(2.5 \mathrm{mM}) ; 100 \mathrm{~mL}$ of $\mathrm{Na}_{2} \mathrm{HPO}_{4}(2.4 \mathrm{mM}) ; 100 \mathrm{~mL}$ of $\mathrm{KHCO}_{3}(1.5 \mathrm{mM}) ; 100 \mathrm{~mL}$ of $\mathrm{NaCl}$ (1.0 mM); $100 \mathrm{~mL}$ of $\mathrm{MgCl}_{2}(0.15 \mathrm{mM}) ; 100 \mathrm{~mL}$ of $\mathrm{CaCl}_{2}(1.5 \mathrm{mM})$; and $6 \mathrm{~mL}$ of citric acid $(0.002 \mathrm{mM})$. The biaxial flexure strength was calculated according to the following equation suggested by Shetty et al. ${ }^{18}$ in the following equations:

$$
\sigma_{f}=\frac{3 F(1+v)}{4 \pi t^{2}}\left[1+2 \ln \frac{A}{B}+\frac{(1-v)}{(1+v)}\left\{1-\frac{B^{2}}{2 A^{2}}\right\} \frac{A^{2}}{R^{2}}\right]
$$

where $\mathrm{F}$ is the load at fracture, $\mathrm{t}$ is the specimen thickness, $\mathrm{A}$ is the diameter of the support circle, $\mathrm{B}$ is the diameter of the tip of the piston, $\mathrm{v}$ is the Poisson's ratio and $\mathrm{R}$ is the radius of the specimen.

Hardness and fracture toughness were determined by making 10 indentations on the polished surfaces of fragments obtained in biaxial flexure test. Specimens were indented in a Vickers microhardness tester (MVK-H-3, Mitutoyo, São Paulo, Brazil), using a load of 19.6 N and dwell time of 20 seconds. Defective indentations (with tortuous cracks, crack branching or chipping) were disregarded. Crack lengths were measured in an optical microscope 30 seconds after the indentation was made on the specimen surface. Vickers hardness (HV) was calculated according to the following equation ${ }^{19}$ :

$$
\mathrm{HV}=\frac{1.8544 P}{d^{2}}
$$

where $\mathrm{P}$ is the load and $\mathrm{d}$ is the mean diagonal of the indentation. Fracture toughness, $\mathrm{K}_{\mathrm{Ic}}$, was calculated according to the following equation $^{20}$ :

$$
\mathrm{K}_{\mathrm{Ic}}=0.016(\mathrm{E} / \mathrm{H})^{0.5}\left(\mathrm{P} / \mathrm{c}^{1.5}\right)
$$

where $\mathrm{P}$ is the indentation load, $\mathrm{c}$ is the size of the median cracks, $\mathrm{E}$ is the Young's modulus and $\mathrm{H}$ is the material's hardness $\left(\mathrm{H}=2 \mathrm{P} / \mathrm{d}^{2}\right.$, where $\mathrm{d}$ is the diagonal of the indentation).

The polished surfaces of the specimens were analyzed by means of optical microscopy (DM RVE, Leica, Germany). The area fraction of porosity was determined by an image analyzer, using three optical micrographs of each material (Leica QWin, Germany). Since the stereology relationship states that the area fraction of pores measured on planar section is equal to its volume fraction ${ }^{21,22}$, hereinafter, the measured area fraction will be addressed as the volume fraction of pores (or porosity). Statistical analysis of all data was performed by means of one-way analysis of variance (ANOVA) and Tukey's test with a global significance level of $5 \%$.

In order to determine possible loss of volatile components of the glass-ceramic during hot-pressing, the weight loss for E2 was determined by thermal gravimetric analysis, TGA (Netzsch, STA 409), in argon atmosphere at a heating rate of $10 \mathrm{~K} / \mathrm{min}$ from room temperature up to $925{ }^{\circ} \mathrm{C}$. This temperature was kept constant for 20 minutes, using about $280 \mathrm{mg}$ of powdered starting sample (ingot).

\section{Results}

For the leucite reinforced glass-ceramic (E1), the results are shown in Table 1. No statistical differences were observed for any 
of the properties tested regardless of the pressing temperature. The coefficient of variation $(\mathrm{CV})$ in the strength test was approximately $13 \%$, except for the group hot-pressed at $1075^{\circ} \mathrm{C}$, which showed a CV of $17 \%$. With respect to porosity, there was a trend for higher values in the $1080{ }^{\circ} \mathrm{C}$ group compared to the other temperatures.

For the lithium disilicate glass-ceramic (E2), the results are presented in Table 2. No statistical differences were observed in biaxial flexure strength, Young's modulus and Poisson's ratio regardless of the temperature. However, porosity was significantly greater for the group pressed at $925{ }^{\circ} \mathrm{C}$ compared to the other temperatures. The $\mathrm{CV}$ for the strength results was approximately $13 \%$ for the groups pressed at 910 and $915{ }^{\circ} \mathrm{C}$, however it increased with the increase in injection temperature, resulting in values of $16 \%$ and $20 \%$ for the groups pressed at 920 and $925^{\circ} \mathrm{C}$, respectively. The Vickers hardness tended to decrease with the increase in injection temperature, and the difference between the values at the lowest $(6.2 \mathrm{GPa})$ and the highest temperature $(5.6 \mathrm{GPa})$ was statistically significant. Fracture toughness varied significantly with temperature and groups hot-pressed at 915 and $925{ }^{\circ} \mathrm{C}$ showed the highest values $\left(\sim 1.7 \mathrm{MPa} . \mathrm{m}^{1 / 2}\right)$. The difference between the highest and the lowest $\mathrm{K}_{\mathrm{Ic}}$ values was approximately $11 \%$.

Figure 1 shows the optical images of the polished surfaces of both materials. Images were selected to highlight differences between the control groups and those pressed at the highest temperatures (1080 and $925^{\circ} \mathrm{C}$, for $\mathrm{E} 1$ and $\mathrm{E} 2$, respectively). It is possible to note that, for both materials, the highest temperature resulted in higher volume fraction of porosity. It is also possible to note that E1 has larger pore sizes compared to E2, regardless of the hot-pressing temperature.

TGA was used to measure weight change after hot-pressing. Such changes may be related to gas release and the formation of bubbles in the microstructure. Figure 2 shows the TGA curves for E2 (E1 was not analyzed by this technique since no statistical differences were observed amongst porosity values). It is possible to note a weight loss of about 0.12 wt. (\%) during the heating stage up to $925{ }^{\circ} \mathrm{C}$ (Figure 2a). In addition, a weight loss of $0.04 \%$ is observed during the isothermal stage at $925^{\circ} \mathrm{C}$ for 20 minutes (Figure $2 \mathrm{~b}$ ).

\section{Discussion}

The results of this study showed that variations in the hot-pressing temperature between 1065 and $1080{ }^{\circ} \mathrm{C}$ do not affect the mechani- cal properties and porosity of the leucite-based glass-ceramic (E1). However, for the lithium disilicate-based material (E2), the pressing temperature significantly affected hardness, fracture toughness and porosity.

With respect to E1, it seems like the microstructure of the material was not affected by the different amounts of energy provided during the hot-press technique, leading to similar mechanical properties in the different temperatures. The E1 ingots provided by the manufacturer are previously subjected to a heat treatment, between 920 and $1200{ }^{\circ} \mathrm{C}$, when leucite grows dendritically from the nucleating centers in the base glass. At the end of this first ceramming heat treatment, which takes approximately one hour, the raw glass-ceramic is ready for further processing in the dental laboratory. In order to achieve the characteristics expected from the final microstructure, a second heat treatment must be performed during the viscous flow stage of the process that results in the final restoration. This process takes place in the furnace used in the present study at $1075{ }^{\circ} \mathrm{C}$ for about 35 minutes. During this time, the leucite crystals undergo a maturing process, resulting in a more homogeneous distribution throughout
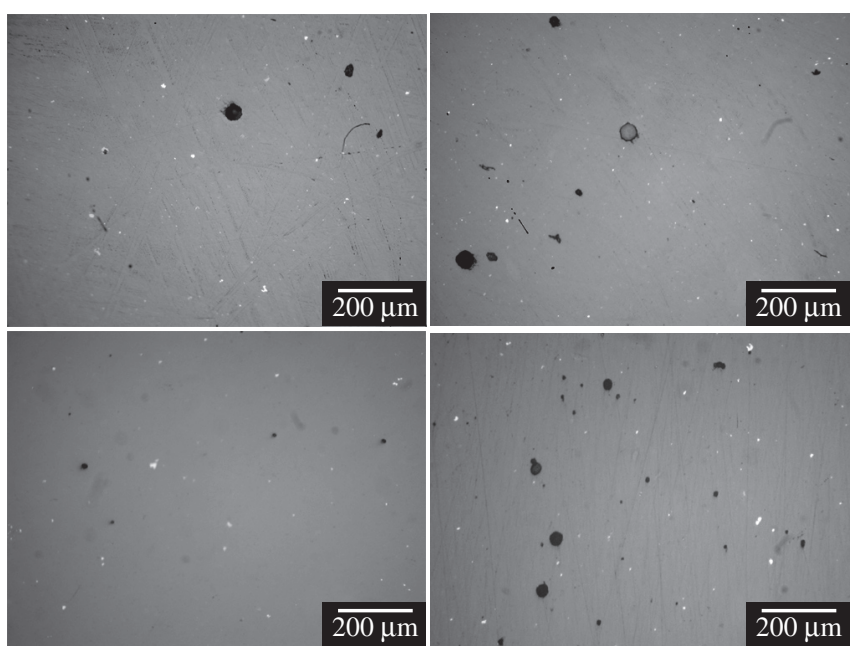

Figure 1. Optical images of polished surfaces of Empress hot-pressed at a) $1075{ }^{\circ} \mathrm{C}$ and b) $1080{ }^{\circ} \mathrm{C}$ and Empress 2 hot-pressed at c) $920{ }^{\circ} \mathrm{C}$ and d) $925^{\circ} \mathrm{C}$.

Table 1. Mean \pm standard deviations for biaxial flexural strength $\left(\sigma_{\mathrm{f}}\right)$ in artificial saliva at $37^{\circ} \mathrm{C}$, Young's modulus (E), Poisson's coefficient $(v)$, Vickers hardness $(\mathrm{HV})$, fracture toughness $\left(\mathrm{K}_{\mathrm{Ic}}\right)$ and volume fraction of porosity $(\mathrm{P})$ for the different pressing temperatures $\left(\mathrm{T}_{\mathrm{p}}\right)$ for Empress. For each property, values followed by the same superscript are statistically similar $(\mathrm{p}>0.05)$.

\begin{tabular}{|c|c|c|c|c|c|c|}
\hline $\mathrm{T}_{\mathrm{p}}\left({ }^{\circ} \mathrm{C}\right)$ & $\sigma_{\mathrm{f}}(\mathrm{MPa})$ & $\mathrm{E}(\mathrm{GPa})$ & $v$ & $\mathrm{HV}(\mathrm{GPa})$ & $\mathrm{K}_{\mathrm{Ic}}\left(\mathrm{MPa} \cdot \mathrm{m}^{1 / 2}\right)$ & $\mathrm{P}(\%)$ \\
\hline 1065 & $112 \pm 14^{\mathrm{a}}$ & $65.6 \pm 1.1^{\mathrm{a}}$ & $0.210 \pm 0.006^{\mathrm{a}}$ & $7.8 \pm 0.5^{\mathrm{a}}$ & $1.22 \pm 0.07^{\mathrm{a}}$ & $1.7 \pm 0.6^{\mathrm{a}}$ \\
\hline 1070 & $99 \pm 13^{a}$ & $67.2 \pm 3.1^{\mathrm{a}}$ & $0.210 \pm 0.009^{\mathrm{a}}$ & $7.6 \pm 0.4^{\mathrm{a}}$ & $1.23 \pm 0.08^{\mathrm{a}}$ & $1.8 \pm 0.9^{\mathrm{a}}$ \\
\hline 1075 & $104 \pm 18^{a}$ & $66.1 \pm 1.1^{\mathrm{a}}$ & $0.210 \pm 0.007^{\mathrm{a}}$ & $7.9 \pm 0.4^{\mathrm{a}}$ & $1.21 \pm 0.05^{\mathrm{a}}$ & $1.9 \pm 0.5^{\mathrm{a}}$ \\
\hline 1080 & $106 \pm 13^{\mathrm{a}}$ & $67.1 \pm 1.2^{\mathrm{a}}$ & $0.211 \pm 0.006^{\mathrm{a}}$ & $7.5 \pm 0.3^{\mathrm{a}}$ & $1.23 \pm 0.06^{\mathrm{a}}$ & $2.6 \pm 0.8^{\mathrm{a}}$ \\
\hline
\end{tabular}

Table 2. Mean \pm standard deviations for biaxial flexural strength $\left(\sigma_{\mathrm{f}}\right)$ in artificial saliva at $37^{\circ} \mathrm{C}$, Young's modulus $(\mathrm{E})$, Poisson's coefficient $(\mathrm{v})$, Vickers hardness $(\mathrm{HV})$, fracture toughness $\left(\mathrm{K}_{\mathrm{Ic}}\right)$ and volume fraction of porosity $(\mathrm{P})$ for the different pressing temperatures $\left(\mathrm{T}_{\mathrm{p}}\right)$ for Empress 2 . For each property, values followed by the same superscript are statistically similar $(\mathrm{p}>0.05)$.

\begin{tabular}{|c|c|c|c|c|c|c|}
\hline $\mathrm{T}_{\mathrm{p}}\left({ }^{\circ} \mathrm{C}\right)$ & $\sigma_{\mathrm{f}}(\mathrm{MPa})$ & $\mathrm{E}(\mathrm{GPa})$ & v & $\mathrm{HV}(\mathrm{GPa})$ & $\mathrm{K}_{\mathrm{Ic}}\left(\mathrm{MPa} \cdot \mathrm{m}^{1 / 2}\right)$ & $\mathrm{P}(\%)$ \\
\hline 910 & $173 \pm 22^{\mathrm{a}}$ & $99.7 \pm 2.3^{a}$ & $0.218 \pm 0.008^{\mathrm{a}}$ & $6.2 \pm 0.4^{\mathrm{a}}$ & $1.51 \pm 0.06^{\mathrm{b}}$ & $0.23 \pm 0.05^{\mathrm{a}}$ \\
\hline 915 & $161 \pm 19^{a}$ & $98.8 \pm 2.2^{\mathrm{a}}$ & $0.229 \pm 0.012^{\mathrm{a}}$ & $5.8 \pm 0.3^{\mathrm{a}, \mathrm{b}}$ & $1.69 \pm 0.08^{\mathrm{a}}$ & $0.15 \pm 0.05^{\mathrm{a}}$ \\
\hline 920 & $171 \pm 27^{a}$ & $99.3 \pm 2.5^{\mathrm{a}}$ & $0.225 \pm 0.012^{\mathrm{a}}$ & $5.8 \pm 0.4^{\mathrm{a}, \mathrm{b}}$ & $1.57 \pm 0.07^{b}$ & $0.18 \pm 0.10^{\mathrm{a}}$ \\
\hline 925 & $179 \pm 35^{\mathrm{a}}$ & $99.0 \pm 1.4^{\mathrm{a}}$ & $0.224 \pm 0.010^{\mathrm{a}}$ & $5.6 \pm 0.3^{b}$ & $1.68 \pm 0.15^{\mathrm{a}, \mathrm{b}}$ & $0.88 \pm 0.11^{\mathrm{b}}$ \\
\hline
\end{tabular}






(a)

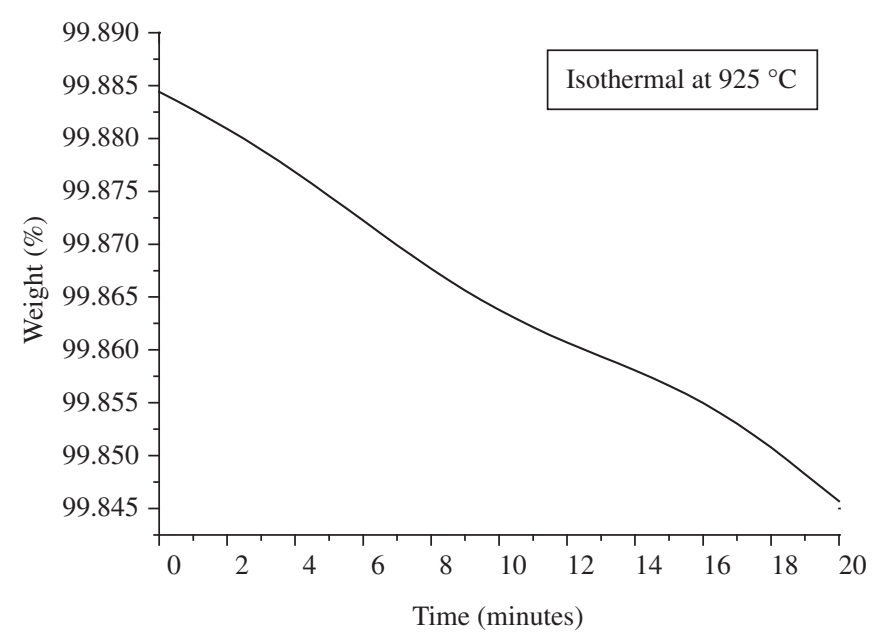

(b)

Figure 2. Thermal gravimetric analysis (TGA) curves for Empress 2: weight loss during heating stage up to a) $925{ }^{\circ} \mathrm{C}$ and under isothermal condition at b) $925^{\circ} \mathrm{C}$.

the glassy matrix ${ }^{5}$. When the viscous flow process is carried out at the temperature recommended by the manufacturer, the crystalline content of E1 (about 30 to 35\% in volume of tetragonal leucite) is not altered ${ }^{3}$. The results of the present study also support the idea that small temperature variations do not affect significantly the crystalline content of E1. The fact that E1 is insensitive to small temperature variations is important from the point of view of the technician, since the absence of furnace calibration will not be a problem on the long term.

Although no statistical differences were detected for E1 results, it should be noted that porosity (volume fraction of pores) tended to be greater when the highest temperature was used. However, the higher porosity in $\mathrm{E} 1 \mathrm{specimens}$ injected at $1080{ }^{\circ} \mathrm{C}$ did not affect the flexural strength. From the Griffith-Irwin relation, the strength, $\sigma_{\mathrm{f}}$, of a brittle material is related to the fracture toughness, $\mathrm{K}_{\mathrm{Ic}}$, and the flaw size, a, as follows ${ }^{23}$ :

$$
\sigma_{f}=\frac{K_{I c}}{Y a^{1 / 2}}
$$

where $\mathrm{Y}$ is a geometrical constant. Considering a penny-shaped surface flaw $\left(Y=1.24^{24}\right)$, the calculated flaw sizes that limited the strength of E1 specimens ranged from $\sim 80$ to $100 \mu \mathrm{m}$, which were significantly higher than the largest pore size observed $(\sim 40 \mu \mathrm{m}$; this size was estimated by measuring the size of the largest pores on the micrographs of the polished surface, Figure 1a and 1b). This analysis indicates that the material's strength was not limited by the pores.

As for E2 glass-ceramic, although some properties were not significantly affected by the variation in injection temperature, it is important to note that the highest temperature $\left(925^{\circ} \mathrm{C}\right)$ showed a trend for higher strength results. The flaw size calculated from the Griffith-Irwin relation (Equation 6) ranged from $\sim 50$ to $70 \mu \mathrm{m}$ for this material, while the pore size observed in the micrographs ranged from $\sim 15$ to $25 \mu \mathrm{m}$ (Figure 1c and 1d). This indicates that the pores did not affect the material's strength in this case either. It is possible that the higher amount of energy provided by the higher temperatures resulted in higher fracture resistance, leading to a slightly higher strength.

In the literature, the biaxial flexure strength values reported for E2 tested in air range from 265 to $407 \mathrm{MPa}$, and the reported mean value is $340 \pm 66 \mathrm{MPa}^{7,8,10,12,25,26}$. The few studies in which the flexural strength of $\mathrm{E} 2$ was determined in distilled water reported a mean value of approximately $215 \mathrm{MPa}^{27,28}$. In the present work, the control group obtained a mean value of $171 \mathrm{MPa}$ in artificial saliva, which is somewhat lower compared to the ones found in the literature. This may be explained by the differences in test method and specimen geometry. While this study used disks with thickness of $1.0 \mathrm{~mm}$ in biaxial flexure design, the above-cited works used bend bars with thickness of $1.2 \mathrm{~mm}$ in uniaxial four-point loading, stored in distilled water for 48 hours at $37{ }^{\circ} \mathrm{C}$ before testing. Another possible explanation for this difference is the fact that lithium disilicate crystals are arranged in different ways depending on the specimen configuration. While in bend bars the crystals are aligned with their long axis parallel to the long axis of the bar, it has been proposed that in disks the crystals are randomly oriented at the surface plane $e^{7,10}$. Therefore, in the bars tested in uniaxial loading, the crystals are aligned perpendicularly to stress orientation, resulting in a strengthening effect. On the other hand, in disks tested in biaxial loading, all directions are evenly stressed in the stress plane, leading to crack propagation through a path of lower resistance.

The fact that the Vickers hardness of E2 tended to decrease with the increase in injection temperature seems to be related with particle coarsening and the increase in porosity. Previous reports indicated that the lithium disilicate crystals became larger after subjected to repeated pressing cycles ${ }^{29}$. It can be speculated that at higher temperatures, this increase in crystal size may have happened, at least to some extent. It has already been demonstrated for polycrystalline ceramics that both the grain growth and the increase in porosity result in a decrease in hardness ${ }^{16,30}$. The fracture toughness results showed that the groups hot-pressed at 915 and $925^{\circ} \mathrm{C}$ presented the highest $\mathrm{K}_{\mathrm{Ic}}$ values, which was not expected. It is possible that a complex interaction among the different phenomena of particle coarsening, particle alignment and porosity led to this type of behavior.

The fracture toughness value obtained for the control group of E2, $1.57 \mathrm{MPa}^{1 / 2}$, was similar to the ones reported by Albakry et al. ${ }^{29}$ using the Indentation Fracture method. However, this value was significantly lower than the ones determined by other methods, which varied from 2.5 to $3.3 \mathrm{MPa} . \mathrm{m}^{1 / 27,8,31}$. According to Albakry et al. ${ }^{29}$, the lower $\mathrm{K}_{\mathrm{Ic}}$ values determined by the IF method are related to the slow crack growth phenomenon that occurs during the 25 seconds between the indentation and crack measurement. 
The significantly higher porosity measured at $925^{\circ} \mathrm{C}$ for E2 is probably related to bubble formation due to the release of dissolved gases $\left(\mathrm{H}_{2} \mathrm{O}, \mathrm{N}_{2}, \mathrm{CO}_{2}, \mathrm{SO}_{2}\right)$ in the interior of the glass and/or entrapped insoluble gases in the initial pores ${ }^{32,33}$. Moreover, the increase in temperature causes a decrease in viscosity, increasing the release and diffusion of gases in the glass matrix. Pascual et al. ${ }^{34}$ reported that for borosilicate glass, when the maximum density is reached, longer treatment times lead to a decrease in density due to degassing and pore formation. Heide and Schmidt ${ }^{35}$ studied the degassing phenomenon in vitreous basaltic rims, using a special high vacuum hot extraction method with quadrupolar mass spectrometer and detected gases such as $\mathrm{H}_{2} \mathrm{O}$ (0.01-0.02 wt. (\%)), $\mathrm{CO}_{2}(0.001-0.002$ wt. (\%)), and $\mathrm{SO}_{2}(0.0001-0.0005$ wt. $(\%))$. The increase in pore size and volume fraction can occur spontaneously in ceramics sintered at high temperatures because of the gas expansion inside the pores caused by pore growth and coalescence ${ }^{36}$. The significant weight loss of $0.04 \%$ observed for E2 when the temperature was kept at $925^{\circ} \mathrm{C}$ for 20 minutes (Figure $2 \mathrm{~b}$ ) indicates that this loss was probably related to gas release, such as water, $\mathrm{CO}_{2}$ and/or $\mathrm{Li}_{2} \mathrm{O}$.

Some gases such as water and $\mathrm{CO}_{2}$ are soluble in the glass ${ }^{37}$. The gas that is entrapped (dissolved) in the glassy matrix can diffuse trough it when the viscosity decreases due to the increase in temperature, leading to the formation (precipitation) and growth of pores in the microstructure. The vaporization of oxides from the glass composition is likely to be the cause of mass loss during the heat treatment, as previously observed in silicate glasses in the temperature range from 1150 to $1300{ }^{\circ} \mathrm{C}^{38}$. A high vaporization rate of $\mathrm{Li}_{2} \mathrm{O}$ at $1400{ }^{\circ} \mathrm{C}$ in the system $\mathrm{Li}_{2} \mathrm{O} \cdot \mathrm{Al}_{2} \mathrm{O}_{3}-\mathrm{Al}_{2} \mathrm{O}_{3}$ was previously reported in the literature ${ }^{39}$. In addition, $\mathrm{Li}_{2} \mathrm{O}$ was added as a transient additive to decrease the sintering temperature of AlN ceramic and resulted in rapid evaporation of this oxide in the temperature range from 1300 to $1600{ }^{\circ} \mathrm{C}$ during the sintering process ${ }^{40}$. Therefore, although $925^{\circ} \mathrm{C}$ is a relatively low temperature compared to the ones used in previous works, it is likely that lithium oxide and/or other oxides evaporated when E2 was exposed to high temperatures. Another study showed that for a leucite based dental porcelain, the weight loss between 200 and $700{ }^{\circ} \mathrm{C}$ was caused by dehydration of hydroxides on the surface of the powder particles. Above $700{ }^{\circ} \mathrm{C}$, the weight loss was a consequence of vaporization of volatile elements $(\mathrm{K} \text { and } \mathrm{Na})^{33}$.

It is important to note that the increased porosity observed for the group pressed at $925^{\circ} \mathrm{C}$ did not lead to a decrease in flexural strength (Table 2). Nonetheless, technicians must be aware that problems with furnace calibration will lead to a change in porosity, hardness and $\mathrm{K}_{\mathrm{Ic}}$ as a function of the injection temperature. Therefore, it is recommended that a calibration schedule is strictly followed during the furnace lifetime.

\section{Conclusion}

Variation in injection temperature did not significantly affect the mechanical properties of Empress (glass-ceramic reinforced with leucite particles). For Empress 2 (glass-ceramic reinforced with elongated lithium disilicate particles), $\mathrm{HV}$ and $\mathrm{K}_{\mathrm{Ic}}$ were significantly higher at 910 and $915^{\circ} \mathrm{C}$, respectively. These changes were caused by particle coarsening and the increase in porosity, which can be attributed to entrapped insoluble gases in the initial pores of the compact and/or bubble formation due to the release of gases dissolved in the glass matrix.

\section{Acknowledgements}

The authors would like to acknowledge FAPESP, CAPES and $\mathrm{CNPq}$ for the financial support of the present research.

\section{References}

1. Braga RR, Ballester RY, Daronch M. Influence of time and adhesive system on the extrusion shear strength between feldspathic porcelain and bovine dentin. Dental Materials. 2000; 16(4):303-310.

2. Cattell MJ, Clarke RL, Lynch EJ. The biaxial flexural strength and reliability of four dental ceramics - Part II. Journal of Dentistry. 1997; 25(5):409-414

3. Gorman CM, McDevitt WE, Hill RG. Comparison of two heat-pressed all-ceramic dental materials. Dental Materials. 2000; 16(6):389-395.

4. MacMillan PW. Glass-ceramics. London: Academic Press; 1979. p. 285 .

5. Holand W, Beall G. Glass-ceramic technology. Westerville: The American Ceramic Society; 2002. p. 385.

6. Cattell MJ, Knowles JC, Clarke RL, Lynch E. The biaxial flexural strength of two pressable ceramic systems. Journal of Denstistry. 1999; 27(3):183-196.

7. Guazzato M, Albakry M, Ringer SP, Swain MV. Strength, fracture toughness and microstructure of a selection of all-ceramic materials. Part I. Pressable and alumina glass-infiltrated ceramics. Dental Materials. 2004; 20(5):441-448.

8. Holand W, Schweiger M, Frank M, Rheinberger V. A comparison of the microstructure and properties of the IPS Empress 2 and the IPS Empress glass-ceramics. Journal of Biomedical Materials Research. 2000; 53(4):297-303

9. Ong JL, Farley DW, Norling BK. Quantification of leucite concentration using X-ray diffraction. Dental Materials. 2000; 16(1):20-25.

10. Albakry M, Guazzato M, Swain MV. Biaxial flexural strength, elastic moduli, and x-ray diffraction characterization of three pressable all-ceramic materials. Journal of Prosthetic Dentistry. 2003; 89(4):374-380.

11. Albakry M, Guazzato M, Swain MV. Fracture toughness and hardness evaluation of three pressable all-ceramic dental materials. Journal of Dentistry. 2003; 31(3):181-188.

12. Oh SC, Dong JK, Luthy H, Scharer P. Strength and microstructure of IPS Empress 2 glass-ceramic after different treatments. International Journal of Prosthodontics. 2000; 13(6):468-472.

13. Dong JK, Luthy H, Wohlwend A, Scharer P. Heat-pressed ceramics: technology and strength. International Journal of Prosthodontics. 1992 5(1):9-16.

14. ASTM-C1161. Standard test method for flexural strength for advanced ceramics at ambient temperature. Philadelphia: American Society for Testing Materials; 2002.

15. JIS-R-1602. Testing method for elastic modulus of fine ceramics. Japanese Standards Association; 1986. p. 16.

16. Yoshimura HN, Molisani AL, Narita NE, Cesar PF, Goldenstein H. Porosity dependence of elastic constants in aluminum nitride ceramics. Materials Research. 2007; 10(2):127-133.

17. ASTM-F394-78. Standard test method for biaxial flexure strength (modulus of rupture) of ceramic substrates. Philadelphia: American Society for Testing Materials; 1996.

18. Shetty DK, Rosenfield AR, McGuire P, Bansai GK, Duckworth W H. Biaxial flexural test for ceramics. American Ceramic Society Bulletin. 1980; 59:1193-1197.

19. ASTM-C1327. Standard test method for Vickers indentation hardness of advanced ceramics. Philadelphia: American Association for Testing Materials; 1999.

20. Chantikul P, Anstis GR, Lawn BR, Marshall DB. A critical evaluation of indentation techniques for measuring fracture toughness: II, strength method. Journal of the American Ceramic Society. 1981; 64(9):539-543.

21. Kurzydłowski KJ, Ralph B. The Quantitative Description of the Microstructure of Materials. $1^{\text {st }}$ ed. Boca Raton: CRC Press; 1995. p. 432.

22. Underwood EE. Quantitative metallography. Materials Park: ASM International; 1985. p. 123-34. 
23. Yoshimura HN, Molisani AL, Narita NE, Manholetti JLA, Cavenaghi JM. Mechanical properties and microstructure of zinc oxide varistor ceramics. Materials Science Forum. 2006; 530:408-413.

24. Mecholsky JJ. Fractography: determining the sites of fracture initiation. Dental Materials. 1995; 11(2):113-116.

25. Fischer H, Dautzenberg G, Marx R. Nondestructive estimation of the strength of dental ceramic materials. Dental Materials. 2001; 17(4):289-295.

26. Jin J, Takahashi H, Iwasaki N. Effect of test method on flexural strength of recent dental ceramics. Dental Materials Journal. 2004; 23(4):490-496.

27. Bona AD, Anusavice KJ, DeHoff PH. Weibull analysis and flexural strength of hot-pressed core and veneered ceramic structures. Dental Materials. 2003; 19(7):662-669.

28. Della-Bona A, Mecholsky-Jr JJ, Anusavice KJ. Fracture behavior of lithia disilicate- and leucite-based ceramics. Dental Materials. 2004; 20(10):956-962.

29. Albakry M, Guazzato M, Swain MV. Influence of hot pressing on the microstructure and fracture toughness of two pressable dental glassceramics. Journal of Biomedical Materials Research: Part B Applied Biomaterials. 2004; 71(1):99-107.

30. Wereszczak AA, Lin H-T, Gilde GA. The effect of grain growth on hardness in hot-pressed silicon carbides. Journal of Materials Science. 2006; 41:4996-5000.

31. Fischer H, Marx R. Fracture toughness of dental ceramics: comparison of bending and indentation method. Dental Materials. 2002; 18(1):12-19.
32. Prado MO, Fredericci C, Zanotto ED. Glass sintering with concurrent crystallisation. Part 2. Nonisothermal sintering of jagged polydispersed particles. Physics and Chemistry of Glasses. 2002; 43(5):215-223.

33. Xiaoxuan L, Shaw LL. Microstructure of dental porcelains in a laser-assisted rapid prototyping process. Dental Materials. 2005; 21:336-346

34. Pascual MJ, Prado MO, Zanotto ED. Model for Sintering Devitrifying Glass Particles with Embedded Rigid Fibers. Journal of the American Ceramic Society. 2005; 88(6):1427-1434.

35. Heide K, Schmidt CM. Volatiles in vitreous basaltic rims, HSDP 2, big island, Hawaii. Journal of Non-Crystalline Solids. 2003; 323(1):97-103.

36. Yoshimura HN, Cruz ACD, Zhou Y, Tanaka H. Sintering of $6 \mathrm{H}(\alpha)-\mathrm{SiC}$ and $3 \mathrm{C}(\beta)-\mathrm{SiC}$ powders with $\mathrm{B} 4 \mathrm{C}$ and $\mathrm{C}$ additives. Journal of Materials Science. 2002; 37(8):1541-1546.

37. Kobayashi H. Advances in Oxy-Fuel Fired Glass Melting Technology. Kyoto: [s.n.]; 2004. p. 1-17.

38. Kassis N, Frischat GH. Vapor pressure of simple silicate glass melts. Journal of the American Ceramic Society. 1981; 64(2):C28-C29.

39. Hummel FA, Sastry BSR, Wotring D. Studies in lithium oxide systems: II, $\mathrm{Li}_{2} \mathrm{O} \bullet \mathrm{Al}_{2} \mathrm{O}_{3}-\mathrm{Al}_{2} \mathrm{O}_{3}$. Journal of the American Ceramic Society. 1958; 41(3):88-92.

40. Watari K, Valecillos MC, Brito ME, Toriyama M, Kanzaki S. Densification and thermal conductivity of AlN doped with $\mathrm{Y}_{2} \mathrm{O}_{3}, \mathrm{CaO}$, and $\mathrm{Li}_{2} \mathrm{O}$. Journal of the American Ceramic Society. 1996; 79(12):3103-3108. 